\title{
People's views towards Gunung Palung National Park, West Kalimantan, Indonesia
}

\author{
JAJAT SUDRAJAT ${ }^{1,2,3, \boldsymbol{v}}$, SITI SAWERAH ${ }^{1}$, NIA PERMATASARI ${ }^{1}$, ANITA SUHARYANI $^{1}$, \\ AMELDALIA KARMONI ${ }^{2}$, GUSTI Z. ANSHARI ${ }^{2,4,5}$, DADANG WARDHANA ${ }^{6}$, DICKO ROSSANDA ${ }^{7}$ \\ ${ }^{1}$ Department of Agricultural Socioeconomics, Faculty of Agriculture, Universitas Tanjungpura. Jl. Prof. Dr. Hadari Nawawi, Pontianak 78124, West \\ Kalimantan, Indonesia. Tel.: +62-561-740191, `email: sudrajat_jajat83@yahoo.co.id \\ ${ }^{2}$ Magister Program in Environmental Studies, Universitas Tanjungpura. Jl. Prof. Dr. Hadari Nawawi, Pontianak 78124, West Kalimantan, Indonesia \\ ${ }^{3}$ Magister Program in Agribusiness, Universitas Tanjungpura. Jl. Prof. Dr. Hadari Nawawi, Pontianak 78124, West Kalimantan, Indonesia \\ ${ }^{4}$ Consortium of Tropical Peat Sciences, Kalimantan Universities Consortium. C/q. Universitas Tanjungpura. Pontianak 78124, West Kalimantan, \\ Indonesia \\ ${ }^{5}$ Department of Soil Science, Faculty of Agriculture, Universitas Tanjungpura. Jl. Prof. Dr. Hadari Nawawi, Pontianak 78124, West Kalimantan, \\ Indonesia \\ ${ }^{6}$ Gunung Palung National Park Authority. Jl. Gadjah Mada, Desa Kali Nilam, Ketapang 78812, West Kalimantan, Indonesia \\ ${ }^{7}$ IJ-REDD+ Project, Indonesia Japan Project for Development of REDD+ Implementation Mechanism, Japan International Cooperation Agency- \\ Directorate of Conservation Forest Environment Services, Ministry of Environment and Forestry, Republic of Indonesia
}

Manuscript received: 29 September 2017. Revision accepted: 24 May 2018.

\begin{abstract}
Sudrajat J, Sawerah S, Permatasari N, Suharyani A, Karmoni A, Anshari GZ, Wardhana D, Rossanda D. 2018. People's views towards Gunung Palung National Park, West Kalimantan, Indonesia. Biodiversitas 19: 1138-1146. It is a common belief that the management of national park prevents local communities from accessing the park and using the park resources. Illegal logging and other unwanted encroachments to the park become a big problem, as national park authority has a limited capacity to monitor the whole park. This research aimed to study how local communities viewed Gunung Palung National Park, which is located in Ketapang and Kayong Utara District, West Kalimantan Province, Indonesia. A total of 91 respondents from seven villages were interviewed. In general, about $70 \%$ of respondents viewed the importance of economic benefits, resulting from limited access to traditional gardens in the use zone of the park and the supply of clean water. Approximately $67 \%$ of these respondents viewed the protection of natural resources in the park was not important. This view was possibly due to their little knowledge of the park management and the use of zoning system in the park. It was reported that park officers have some activities, but the collaboration and relationship between park officers and local communities need more time to mature. It seems that the poor and the youth tend to exploit more and put higher pressures on the park than the elderly groups. $\square$
\end{abstract}

Keywords: Local people, national park management, perception, social problems

\section{INTRODUCTION}

The presence of national park as a conservation area has a strategic role in today's era. The benefits of forests are increasingly felt when the area of forests continues to decrease. Currently, the majority of the remaining forest is located in conservation areas, including national parks. However, in many cases, the presence of national parks raises several social problems (Verbist and Pasya 2004; Hollenbach 2005; Langton et al. 2005; Silori 2007; Yogaswara 2009; Deni 2011; Diantoro 2011; Karanth and Nepal 2011; Garner et al. 2012; Kadir et al. 2012; Kadir et al. 2013; Mir et al. 2015; Nastran 2015; Nastran and Istenic 2015; Rawat and Chandra 2015; Tadesse and Taketay 2017). For example, villagers around the park assume that they have lost access to forest resources and land ownership due to the presence of national parks. In fact, they had already inhabited the area for a thousand of years before the national parks was established, or they firstly have been in the area before the management of the park is present. This phenomenon could lead to a social conflict between the local people (the villagers) and the national park's authority.

These social problems also occur in Gunung Palung National Park (GPNP), a conservation area located in West Kalimantan Province, Indonesia. The most prominent problem is a conflict of access to the lands surrounding the village adjacent to the national park, both for settlement and agricultural purposes. In addition, up to now, this park still faces encroachment problems, particularly illegal logging activities. Access conflicts were more intensified after the government expanded this conservation area from an approximately 90,000-hectare area in 1990 (based on Forestry Ministerial Decree Number 448/Menhut-VI/1990) to about 108,043.90 hectares in 2014 (based on Decree of the Minister of Forestry Number 4191/MenhutVII/KUH/2014). In addition, the villagers around the park also continue to put pressure on the officers, especially regarding the land loss and limited access to forests due to the expansion of oil palm plantation. Currently, oil palm plantations have already been established on almost all sides (south, north, east) of the park. Furthermore, it will increase the pressure on conservation and also change the 
local people's perceptions toward the existence and benefits of natural forests in the park.

As a response to the increasing conflicts and pressures, the GPNP authority since 2013 has prepared preliminary development of a resort based management system (RBM) by optimizing the role of national park officials in collaborating with local communities in park management. Until today, the effectiveness of RBM remains unknown. Positive perceptions on the presence of the park and work performance of resort officers can be an indicator of the effectiveness of RBM. In fact, perception is the determinant of the attitude and behavior of a person toward the park (Nastran 2015). The positive and negative perception toward the park may be influenced by people dependence on park resources, management intervention from park authority, benefits and losses, government policy, and experiences. Positive attitude toward the park management is influenced by socioeconomic demographic characteristic and knowledge (Htun et al. 2012).

Until recently, the questions about local people's perceptions related to the GPNP management and the knowledge of local people on the current park management zone remained unanswered. Therefore, it is important to identify the people's perception toward the park management, as a part of assessing the effectiveness of management and determining the next steps in conservation management initiatives. This study generally aimed to investigate the local people perception. Specifically, the objectives this study were (i) to collect perception of local people on the park existence and benefits, (ii) to identify knowledge and perception of local people on the current park management, consisting of people knowledge of GPNP zones and rules, commitment and independent support for conservation, and work performance of resort officers.

\section{MATERIALS AND METHODS}

\section{Study area}

This study was conducted from May to September 2017. At this phase, we covered only Kayong Utara District, the western side of the park. This location is not far from coastal areas (Figure 1). This figure also shows the distribution of villages surrounding GPNP. Overall, the national park region also covers Ketapang District, on the eastern side of the park. Geographically, this park lies between $01^{\circ} 03^{\prime}-01^{\circ} 22^{\prime} \mathrm{S}$ and $109^{\circ} 54^{\prime}-110^{\circ} 28^{\prime} \mathrm{E}$. This region has been established as a conservation area because it has some unique natural resources, in terms of its flora and fauna diversity. The region is frequently perceived as one of the best and largest dipterocarp forests in Borneo. It is estimated that about $65 \%$ of the area is still in the form of primary forest. It still has many communities of plants and animals. In addition, it has various types of forest ranging from coastal areas in the form of mangrove forests, swamp forests, lowland dipterocarp forests, low mountain forests and upland forests. GPNP also supports rare wildlife habitats, that is as the largest habitat for Orangutan population (Pongo pygmaeus) in Borneo, Bekantan
(Nasalis larvatus) as endemic species of Borneo, six species of hornbills (e.g., Buceros vigil), species of bats, and some species of other primates. Referring to International Union of Conservation of Nature (IUCN), the park authority divides this park into nine zone: core zone $(32.80 \%)$, specific zone for public facilities $(0.03 \%)$, specific zone for residential $(0.08 \%)$, specific zone for cultivation $(9.71 \%)$, utilization zone $(6.13 \%)$, rehabilitation zone $(3.41 \%)$, religious zone $(0.31 \%)$, forest zone $(42.59 \%)$, and traditional zone (4.93\%) (TNGP 2009).

\section{Procedures of data collection}

We did a reconnaissance study prior to data collection. This stage helped us to (i) select the villages around the park, (ii) comprehend general understanding of the situations near the park, and (iii) examine the effectiveness of the questionnaire.

Main data were collected in two different ways, namely structured and unstructured interviews. Structured interviews were conducted on households as sample units, using a questionnaire as the primary data collection tool. The questionnaire had both open and close-ended questions to collect much information concerning socio-economic conditions and people's perception of park management. Besides, there were also unstructured interviews with selected key informants intended to obtain more in-depth information about various aspects related to community perceptions as well as the potential for pressure on conservation. Unstructured interviews were also used as a means of cross-checking the information that was gathered with structured interviews. These interviews were conducted face to face in the afternoon or evening with the intention that the respondents could feel comfortable during the interview. $\square$

The household samples were selected in two stages. First, we did a household spatial mapping in each sample village. Then, in the second stage, we selected households in each village using simple random sampling. Meanwhile, the number of sample villages was determined purposively. Seven hamlets (dusun, kampung) in four villages (desa) were chosen which possibly could represent all characteristics of the villages adjacent to the park (see Figure 1). These villages were Batu Barat (Matan Raya hamlet), Sedahan Jaya (Sawah, Tanjung Banjar, and Begasing hamlets), Pangkalan Buton (Air Pauh hamlet), and Sejahtera (Tanjung Gunung and Melinsum hamlets) of Kayong Utara District, West Kalimantan, Indonesia.

The number of sample households for the purpose of structured interviews in each village was $10 \%$. Thus, in total, we interviewed 91 households. Meanwhile, for unstructured interviews with key informants, the survey team successfully interviewed ten people, consisting of village heads, elderly villagers, and community leaders.

\section{Data analysis}

To explain two research objectives, data analyses were done by combining descriptive qualitative analysis and quantitative analysis. Qualitative analysis basically included the synthesis and verification of several aspects that could not be measured quantitatively. On the other 
hand, the measurement of quantitative perceptions was carried out as follows. First, we measured perceptions of the existence and benefits of GPNP, which was a subjective assessment of the importance of the presence of GPNP, based on the number of scores of questions on (i) perceptions on the existence of GPNP. These questions included: income of the non-timber for future expectation, environmental comfort, and natural balance, and (ii) perceptions of the benefits of GPNP. These questions comprised: current non-timber revenue benefits, clean water, and recreation. Each of these assessments amounted to 3 items, with a score index of 3 levels. Each rating had the lowest score of 3 and the highest score of 9. They subsequently were grouped into the following categories: more than 7 (good), between 5-7 (moderate), and less than 5 (poor). Meanwhile, for the measurement of overall perception level on existence and benefit was done by summing the 6 items of the question, thus obtaining the lowest score of 6 and the highest score of 18 and they were subsequently grouped in the following categories: more than 14 (good), between 10-14 (moderate), and less than 10 (poor).

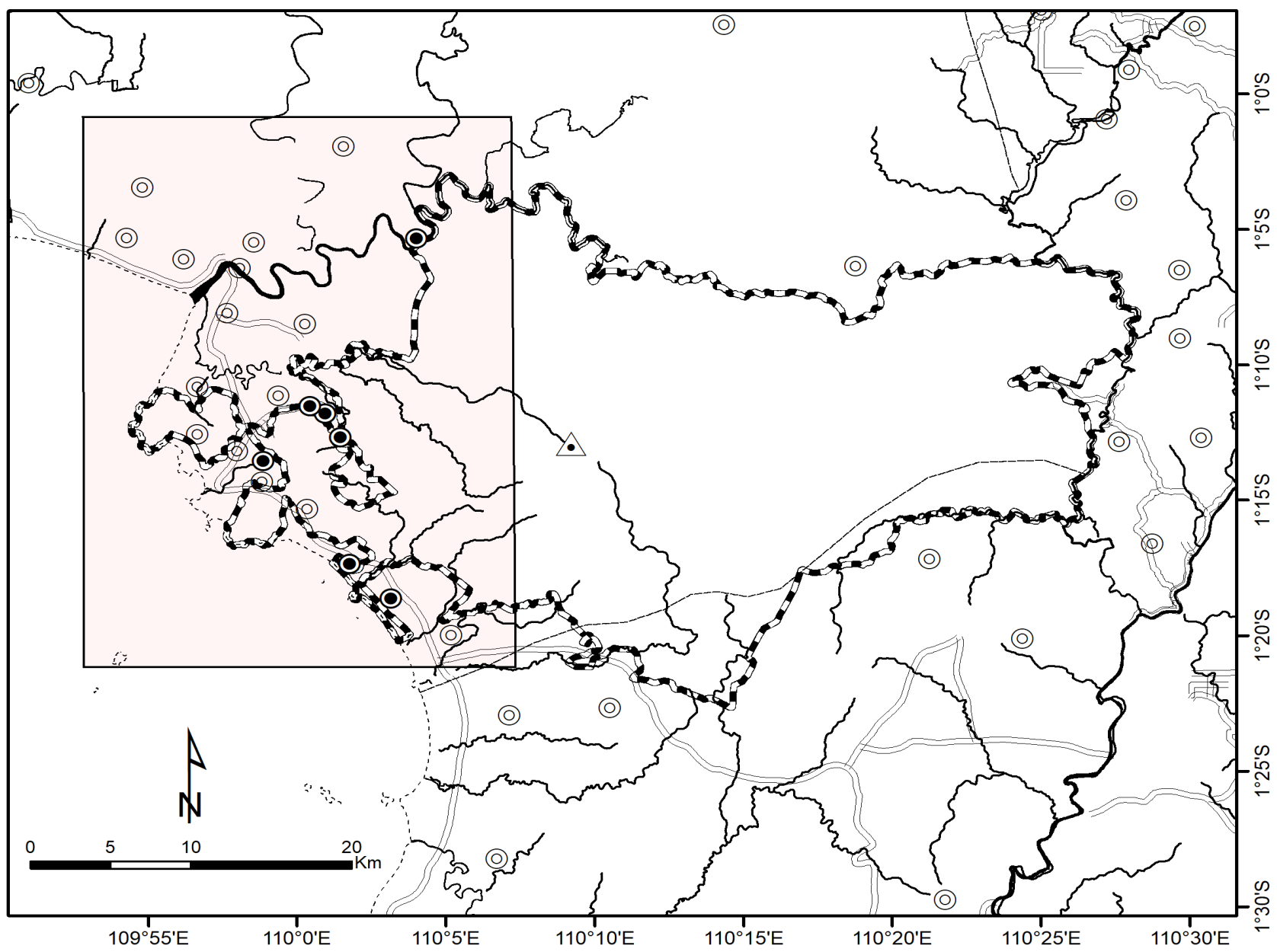

Legend

๑ Mountain

O Surveyed Village

(C) Village

Road

River Stream

-..... District Boundary

GPNP Boundary Survey Area

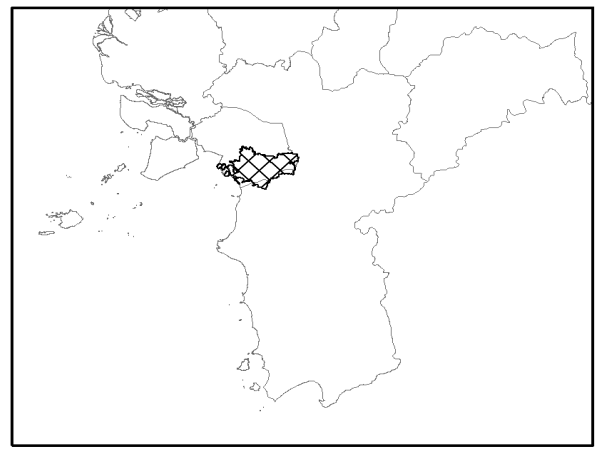

West Kalimantan Province

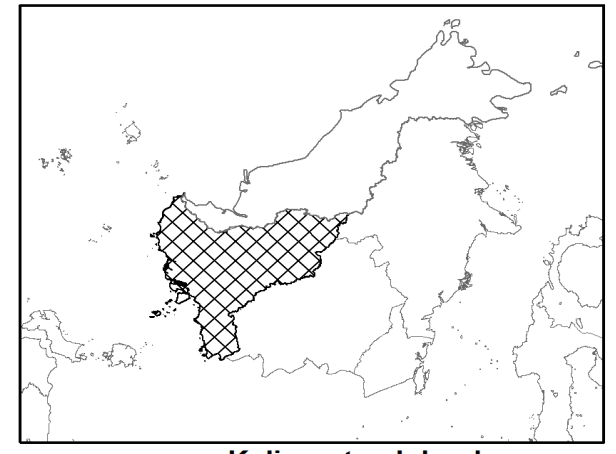

Kalimantan Island

Figure 1. A map showing the location of Gunung Palung National Park, West Kalimantan, Indonesia and villages surrounding the park 
Second, we measured the community's knowledge about GPNP, namely the people's understanding of zoning and GPNP regulation. It was measured by the number of scores of 5 questions. These questions were knowledge about zone types of GPNP, park boundaries, prohibitions for construction in park zone, prohibitions of cultivation outside of special zones, and knowledge about allowed utilization of non-timber forest products. The questions were 5 items with a score index of 3 . The lowest score was 5 and the highest score was 15 . Then, they were grouped into the following categories: more than 12 (good), between 9-12 (moderate), and less than 9 (poor).

Third, we measured the community's commitment and independent support to conservation. This section was measured by two indicators, namely the involvement in the conservation of GPNP and the independent support for conservation. The involvement in GPNP conservation was measured by three questions: (i) whether the informant had ever taken timber in the GPNP zone for the construction of one's own house, family, or friend, (ii) whether the informant had ever taken timber in the GPNP zone for sale, and (iii) whether the informant had ever cleared forest to make farmland in the GPNP zone. Similarly, independence was measured by three questions, as follows: (i) does the informant have a farm or non-farm business that can provide fulfilment of living needs?, (ii) does the informant ever plant timber or take care of timber in the GPNP zone for reforestation purposes?, (iii) had he/she ever prevented or advised anyone not to take timber in the GPNP zone? The question of each assessment was 3 items with a score index of 3 levels. Each rating had the lowest score of 3 and the highest score of 9 . They were subsequently grouped into the following categories: more than 7 (good), between 5-7 (moderate), and less than 5 (poor). Meanwhile, for the measurement of overall commitment and independent support for conservation, it was done by adding 6 items of questions. Thus, it obtained the lowest score of 6 and the highest score of 18 and subsequently grouped in the following categories: more than 14 (good), between 10-14 (moderate), and less than 10 (poor).

Fourth, we measured people's perception on the work performance of GPNP officers using two questions, i.e.: (i) whether the respondents know or feel attached to the resort officers, and (ii) whether the GPNP officers patrol is required to preserve forests and informants are happy with the patrols. These questions consisted of 2 items with index score of level 3 . Hence, the lowest score was 2 , and the highest score was 6 , and they were subsequently grouped in category as follows: more than 4 (good), between 3-4 (moderate), and less than 3 (low).

In addition, statistical data analysis to obtain an inferential statistics was also used, namely Pearson ChiSquare to explain a relationship or phenomenon that occurred in the behavior of the observed community. We analyzed the correlation between socioeconomic, demographic characteristic and support for conservation. We used Statistical Package for Social Sciences (SPSS) software version 20 to conduct data analysis.
It is important to note that p-value is traditionally less than 0.01 and 0.05 used to reject null hypothesis (Schneider 2013). However, this statistical test is used to interpret what local communities view on conservation, and this is not just to accept or reject null hypothesis (Peeters 2016). In addition, sample size is also relatively large (Khalilzadeh and Tasci 2017). In this study, a p-value greater than 0.05 but less than 0.1 is considered important or has some significant influence on conservation supports by local communities. $\square$

\section{RESULTS AND DISCUSSION}

\section{Socio-economic condition of local communities}

Before analyzing people's perceptions, this section begins with a description of the social and economic conditions of the community. The results (Table 1) showed that the locations near GPNP had been inhabited by various ethnic groups with the majority of Kayong Malay ethnic $(64.84 \%)$. The respondents' age ranged from 27 until 77 years with an average of 47 years. The family size was an average of four people. In terms of educational level, most respondents (62.64\%) only accomplished primary school. The majority of respondents $(90.11 \%)$ had mixed farming, cultivating various commodities, while the remaining, about $9.89 \%$, worked in non-agricultural sector. $\square$

In terms of income, the majority of households $(67.03 \%)$ could be grouped as poor with monthly income of $\leq 2$ million IDR, about $24.18 \%$ of respondents had an income level around 2-3 million IDR, and approximately $8.79 \%$ respondents obtain over 3 million IDR. The poor category in this analysis was based on the World Bank poverty standard, that is household income of $<1$ USD per capita per day, with IDR exchange rate at the time of study, was 1 USD $=13,200$ IDR. The dominant land farm was paddy fields, i.e., $75.82 \%$, while rubber plantation was about $10.99 \%$ and traditional gardens within the GPNP zone was about $18.68 \%$ (Table 1).

A mixed farming was the most common livelihood around the park. Villagers mainly cultivated paddy rice, rubber and durian (as cash crop), other fruit trees, and other seasonal crops. They also reared small-scale livestock, such as goat and chicken, and had small-scale fisheries. Besides, some villagers living adjacent to the park had a traditional garden in the park. It was a mixed garden within the park zone consisting of various species of fruit plants, such as durian, banana, sugar palm, etc. Durian was a main seasonal fruit planted in the garden within the current park boundary. It was common that indigenous communities (i.e., the Dayak people) practice shifting cultivation, collect non-timber forest products, and hunt wildlife (Dove 1988).

\section{Perceptions on the existence and benefits of GPNP}

Perceptions on the existence were a subjective view of society on indirect use values, such as long-term benefit assessments, whereas perceptions on benefits are views of direct use values. The results of the analysis are presented in Table 2. 
Table 1. Socioeconomics characteristic of respondents

\begin{tabular}{|c|c|c|}
\hline Variables & $\begin{array}{l}\text { Respondents } \\
\text { characteristic }\end{array}$ & $\begin{array}{l}\text { Pro- } \\
\text { portion } \\
(\%)\end{array}$ \\
\hline Number of samples (n) & 91 households & \\
\hline Age & $27-77$ yrs, average $=47$ yrs & \\
\hline Family size & Average $=4$ people & \\
\hline \multirow[t]{7}{*}{ Ethnicity } & Kayong Malay & 64.84 \\
\hline & Dayak & 1.10 \\
\hline & Buginese & 8.79 \\
\hline & Balinese & 5.49 \\
\hline & Javanese & 4.40 \\
\hline & Madurese & 8.79 \\
\hline & Others & 6.62 \\
\hline \multirow[t]{5}{*}{ Education } & Illiterate & 17.58 \\
\hline & Primary school & 62.64 \\
\hline & Junior high school & 10.99 \\
\hline & Senior high school & 5.49 \\
\hline & University & 3.30 \\
\hline \multirow[t]{2}{*}{ Occupation } & Mixed farming & 90.11 \\
\hline & Non farm & 9.89 \\
\hline \multirow[t]{6}{*}{ Income level } & $0-500,000$ IDR & 9.89 \\
\hline & $500,500-1,000,000$ IDR & 10.99 \\
\hline & $1,000,500-1,500,000$ IDR & 16.48 \\
\hline & $1,500,500-2,000,000$ IDR & 29.67 \\
\hline & $2,000,500-3,000,000$ IDR & 24.18 \\
\hline & $>3,000,000 \mathrm{IDR}$ & 8.79 \\
\hline \multirow{2}{*}{$\begin{array}{l}\text { Do you have rubber } \\
\text { farming? }\end{array}$} & Yes & 10.99 \\
\hline & No & 89.01 \\
\hline \multirow[t]{2}{*}{ Do you have rice farming? } & Yes & 75.82 \\
\hline & No & 24.18 \\
\hline \multirow{2}{*}{$\begin{array}{l}\text { Do you have traditional } \\
\text { garden in GPNP zone? }\end{array}$} & Yes & 18.68 \\
\hline & No & 81.32 \\
\hline
\end{tabular}

Table 2. Perception on the existence and benefits of GPNP, West Kalimantan, Indonesia

\begin{tabular}{|c|c|c|c|c|}
\hline Variables & $\begin{array}{l}\text { Scoring } \\
\text { category* }\end{array}$ & $\begin{array}{l}\text { Respon- } \\
\text { dents (n) }\end{array}$ & $\begin{array}{c}\text { Pro- } \\
\text { portion } \\
(\%) \\
\end{array}$ & $\begin{array}{c}\text { The } \\
\text { average } \\
\text { of score }\end{array}$ \\
\hline \multirow{3}{*}{$\begin{array}{l}\text { Overall perception } \\
\text { on the existence } \\
\text { and benefits of } \\
\text { GPNP }\end{array}$} & Good $(>14)$ & 65 & 71.43 & \multirow[t]{3}{*}{15.98} \\
\hline & Moderate (10-14) & 25 & 27.47 & \\
\hline & Poor $(<10)$ & 1 & 1.10 & \\
\hline \multirow{3}{*}{$\begin{array}{l}\text { Perception on the } \\
\text { existence of } \\
\text { GPNP }\end{array}$} & $\operatorname{Good}(>7)$ & 65 & 71.43 & \multirow[t]{3}{*}{8.22} \\
\hline & Moderate (5-7) & 25 & 27.47 & \\
\hline & Poor $(<5)$ & 1 & 1.10 & \\
\hline \multirow{3}{*}{$\begin{array}{l}\text { Perception on the } \\
\text { benefits of GPNP }\end{array}$} & Good $(>7)$ & 53 & 58.24 & \multirow[t]{3}{*}{7.76} \\
\hline & Moderate (5-7) & 36 & 39.56 & \\
\hline & Poor $(<5)$ & 2 & 2.20 & \\
\hline
\end{tabular}

Results of the analysis indicated that about $71.43 \%$ of households had good (positive) perception. This means that the presence of GPNP can provide an important value in terms of its existence and benefits to the local people in western side of the park. The good perception is very beneficial in supporting the success protection of this conservation area in the future. Those who had good perception were from the villages of Air Pauh (83.33\%), Melinsum (77.78\%), Begasing (70\%), Sawah (66.67\%),
Table 3. Local people's knowledge about zoning and GPNP rules, West Kalimantan, Indonesia

\begin{tabular}{llccc}
\hline Variables & $\begin{array}{l}\text { Scoring } \\
\text { category* }\end{array}$ & $\begin{array}{c}\text { Respon Propor- } \\
\text {-dents } \\
\text { (n) }\end{array}$ & $\begin{array}{c}\text { The } \\
\text { to) }\end{array}$ & $\begin{array}{c}\text { The } \\
\text { average } \\
\text { of score }\end{array}$ \\
\hline Level of knowledge & Good $(>12)$ & 7 & 7.69 & 9.22 \\
& Moderate $(9-12)$ & 52 & 57.14 & \\
& Poor $(<9)$ & 32 & 35.16 & \\
GPNP zoning & Good & 4 & 4.40 & - \\
knowledge & Moderate & 6 & 6.59 & - \\
& Poor & 81 & 89.01 & - \\
Knowledge of park & Good & 49 & 53.85 & - \\
boundary & Moderate & 14 & 15.38 & - \\
& Poor & 28 & 30.77 & - \\
Knowledge about pro- & Good & 65 & 71.43 & - \\
hibition to construction & Moderate & 10 & 10.99 & - \\
in GPNP zones & Poor & 16 & 17.58 & - \\
Knowledge about pro- & Good & 10 & 10.99 & - \\
hibition to cultivation on & Moderate & 4 & 4.40 & - \\
the outside of special zones & Poor & 77 & 84.62 & - \\
Knowledge allows & Good & 40 & 43.95 & - \\
utilizing non-timber & Moderate & 14 & 15.38 & - \\
forest products & Poor & 37 & 40.66 & - \\
\end{tabular}

Note: ${ }^{*}$ scoring numbers in the bracket

Tanjung Banjar (66.67\%), Matan Raya (66.67\%), and Tanjung Gunung (63.64\%). Referring to some benefits that had already been felt by the community, this good perception was closely related to the presence of the benefits of clean water and traditional gardens in the first five villages. As for Matan Raya villagers, it was closely related to the benefits of Matan River water as a source of household water supply, the quality of which was influenced by the existence of GPNP. Meanwhile, on the other side, there were oil palm plantations around the village which they extremely worried, might cause water pollution. In Tanjung Gunung village, there was no clean water or the traditional gardens that could be directly utilized. Hence, the good perception scores were the least, compared to other villages.

\section{People's knowledge about GPNP zones and rules}

Rural resident knowledge about zoning system in the park and also its rules is an important indicator to know the intensity of communication between the local people and park officers. The GPNP has nine zones, and it should be known by the local people near this protected area. This knowledge is important, because some aspects will determine the planning of each zone. The results of this analysis are presented in Table 3.

The analysis in Table 3 shows that the local people around GPNP in Kayong Utara District had poor knowledge about zoning system and GPNP rules. The proportion of respondents having poor knowledge level was $35.16 \%$, moderate knowledge $57.14 \%$, and good knowledge only $7.69 \%$. These results indicated a lack of good communication between park officers and local people in the delivery of regulations and management zones. 
The low level of people's knowledge was largely caused by their low knowledge about zoning system, because only about $4.4 \%$ of people had a good understanding, while about $89.01 \%$ of people did not really understand about the division of zones. This result is very worrying because the zoning system is basically a management implementation of GPNP that should not only be known by the GPNP's officers and government agencies but also by public as part of the involvement of the community in the management.

Local communities had low knowledge on the functions of zones in the park. There was low knowledge that the farming in the GPNP zone should only be done in a special zone for cultivation. The proportion of people who knew this rule was only $10.99 \%$. About $84.62 \%$ did not know it at all, and $4.40 \%$ was ensured. Similarly, the knowledge on the collection of non-timber forest products was relatively low. The people who knew this rule was only about $43.95 \%$, and the rest $56 \%$ did not know at all. Some local communities believed that taking foodstuff such as young bamboo was considered as an offense. $\square$

People's knowledge about park boundaries was good enough; about $53.85 \%$ of respondents knew it, and the remaining $46.15 \%$ did not know and was less likely to know. The people's knowledge about outer boundary was mainly obtained from information independently heard from friends in their daily activities around the village. The natural boundaries such as rivers seemed more easily remembered by people than other boundary forms, such as concrete poles. Similarly, $71.43 \%$ of respondents knew on the ban of building houses and other buildings in the GPNP zones, while $17.58 \%$ did not know and $10.99 \%$ was less likely to know. Knowledge of this rule was largely derived from the existence of various cases concerning the problem of house construction in the GPNP's zones, and such cases spread more quickly in the public.

\section{Commitment and independent support for conservation}

The commitment in this study was expressed as a willingness of respondents to uphold a rule or norm and a willingness to exert all efforts in doing it, particularly to protect timber in GPNP. Meanwhile, independence was defined as the potential of individuals or households in fulfilling the needs of their lives that did not depend on natural forest resources especially timber. The results of the analysis are presented in Table 4.

Table 4. Commitment and independent support for conservation

\begin{tabular}{|c|c|c|c|c|}
\hline Variables & Scoring category* & $\begin{array}{l}\text { Respon- } \\
\text { dents } \\
\text { (n) }\end{array}$ & $\begin{array}{c}\text { Pro- } \\
\text { portion } \\
(\%)\end{array}$ & $\begin{array}{l}\text { The } \\
\text { average } \\
\text { of score }\end{array}$ \\
\hline $\begin{array}{l}\text { Level of committed } \\
\text { and independent supports } \\
\text { for protection (overall) }\end{array}$ & $\begin{array}{l}\text { Good }(>14) \\
\text { Moderate }(10-14) \\
\text { Poor }(<10)\end{array}$ & $\begin{array}{l}30 \\
59 \\
2\end{array}$ & $\begin{array}{l}32.97 \\
64.84 \\
2.20\end{array}$ & 13.59 \\
\hline $\begin{array}{l}\text { Committed to park } \\
\text { protection }\end{array}$ & $\begin{array}{l}\text { Good }(>7) \\
\text { Moderate }(5-7) \\
\text { Poor }(<5)\end{array}$ & $\begin{array}{l}61 \\
29 \\
1\end{array}$ & $\begin{array}{l}67.03 \\
31.87 \\
1.10\end{array}$ & 7.98 \\
\hline $\begin{array}{l}\text { Independent supports } \\
\text { for protection }\end{array}$ & $\begin{array}{l}\text { Good }(>7) \\
\text { Moderate }(5-7) \\
\text { Poor }(<5)\end{array}$ & $\begin{array}{l}12 \\
54 \\
25\end{array}$ & $\begin{array}{l}13.39 \\
59.34 \\
27.47\end{array}$ & 5.62 \\
\hline
\end{tabular}

Note: * scoring numbers in the bracket
The results of the analysis as shown in Table 4 indicate that the majority of the villagers in Kayong Utara District had a low level of commitment and independent support for conservation. They had poor to moderate support for preserving GPNP. Members of the community who had a poor in overall commitment and independent support for conservation was around $2.20 \%$. Those belong to moderate category were about $64.84 \%$ and in good category only $32.97 \%$. The people in poor category did not support preservation, while those in good category fully supported conservation. Meanwhile, the moderate category might support conservation at one time, but in certain conditions, they might be the opposite. These results also mean that approximately $67 \%$ of the community members did not consider GPNP forest protection important. This phenomenon was inferred from the level of independent support for conservation which was very low. It was only $13.39 \%$ of respondents were considered as good, 59.34\% moderate and $27.47 \%$ poor. This result was contrary to commitment (Table 4), but consistent with the income level of the community, which showed that about $67.03 \%$ of respondents fall in poor, with monthly income level of $\leq 2$ million IDR (Table 1). The lack of independent supports for protection is a serious threat to the management of GPNP.

\section{Perception toward work performance of resort officers}

The GPNP management has done several actions to protect this conservation area such as preparing a resortbased protection management system (RBM). This is understandable because the resort level is a direct institution for implementing protection programs. It means that the reliable resort officers play a key role in the success of the park protection. As a management implementation, since 2013 the resort officers have been trained on communications skill, including the smart patrol skill, participatory approaches, and other aspects. The work performance of resort officers as perceived by local communities is presented in Figure 2.

Figure 2 shows that the communities around GPNP had a fairly good perception level on the work performance of the resort officers in communicating the messages of park protection management. Good perception rate reached $47.25 \%$, while the moderate and low perceptions were $47.25 \%$ and $5.49 \%$ respectively. Even though the perception of about patrol was good (74.73\%), but friendship with resort officers was still very low. Members of the community who felt less familiar to the resort officer were about $29.67 \%$ and those who did not know at all $46.15 \%$.

\section{Selected demographic variables influencing conservation support}

To get the understanding of the community's behavior, this study analyzed the relationships between socioeconomic demographic variables and supports for conservation. The result of analysis showed that there was a significant correlation between household income and independent supports for conservation (Pearson Chi-Square $=20.396, \mathrm{df}=4, \mathrm{p}=0.000)$. The higher household income 

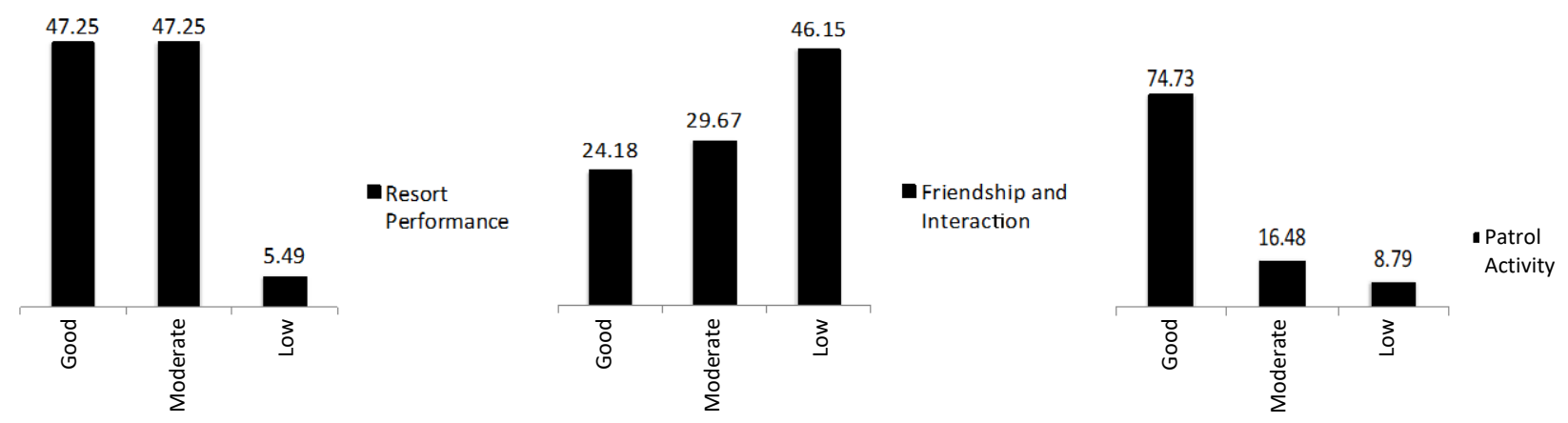

Figure 2. Perception of resort performance, friendship with resort officer, and patrol activity

showed higher positive support for conservation than the lower income. Similarly, there was a significant correlation between respondent's age and independent supports for conservation (Pearson Chi-Square $=8.609$, df $=4, \mathrm{p}=$ 0.072 ). Older people were more supportive to conservation than the younger. Conversely, the education level did not correlate with independent supports for conservation (Pearson Chi-Square $=4.152, \mathrm{df}=4, \mathrm{p}=0.188$ ).

\section{Discussion}

Several factors influence people's perception on the park. In this study, high perceptions on the existence and benefits of GPNP were related to benefits of clean water for household consumption all year round, site for recreation, and utilization zone for traditional gardens (i.e., durian trees). The utilization of clean water and the traditional gardens were found in several villages, such as in Sawah, Tanjung Banjar, Begasing, Air Pauh, and Melinsum village. However, there were no such facilities in Matan Raya and Tanjung Gunung village. This information suggests that improving the benefits of clean water and the traditional gardens in each adjacent village are an important tool for nurturing and improving people perceptions. In other words, these findings imply that community access to park benefits is a crucial component in creating the positive perceptions (Fiallo and Jacobson 1995; Silori 2007; Karanth and Nepal 2011; Garner et al. 2012; Nastran 2015; Nastran and Istenic 2015).

Although positive perceptions toward the existence and benefits of the park reached $71.43 \%$ (Table 2), it does automatically reflect the positive attitude toward conservation, as evidence in this study; but it was not followed by level of commitment and independent supports for conservation (Table 4). It seems that a positive attitude towards the existence of a national park only suggests that local communities acknowledge the existence of the park, and may reflect a room for cooperation between local people and the park management, but it does not always fully guarantee the real action of local communities in the practice of conservation (Mamo 2010). Similar positive perceptions towards the presence of the park had been found before, such as reported by Infield (1988), Mamo (2010), Osunsina (2015), and Megaze et al. (2017).

There are several aspects that explain lacks independence in conservation supports if it is related to some socio-economic characteristics of the community. The result of statistical analyses showed that the independence to preserve GPNP was predominantly related to the level of household income, and the age of the respondents. It means that the elderly are more likely to support conservation than the young. This finding suggests that an approach to young household groups in villages or hamlets around GPNP is important for improving the effectiveness of park protection management initiatives. Usually, productive age groups are often involved in many community activities including deforestation to earn income (Osunsina 2015). This result contradicts to previous findings which show that the elderly tend to be less likely to support park preservation than the youth (Newmark et al. 1993; Fiallo and Jacobson 1995; Arjunan et al. 2006; Shibia 2010; Megaze et al. 2017). The lack of support of the older age is related to the experiences before (Shibia 2010) or fear that the park would threaten their livelihood, such as for grazing, fuel-wood, and other forest product (Megaze et al. 2017). Conversely, independence for conservation was not influenced by levels of education. The last result is consistent with Nastran and Istenic (2015) findings, which indicate that education does not affect population support for the park. It can be explained that the fulfillment of livelihood determines the behavior of individuals more than other aspects such as education.

Furthermore, results of the analyses also show that the income level was the most important determinant of conservation because the income affects the interaction between local people and forest resources. These results are in line with the findings of Silori (2007) and Megaze et al. (2017) which reveal that the promotion of income increase is an important alternative in reducing community dependence on national parks. In other words, an increase in people's incomes is an important factor that leads to the protected conservation area (Karanth and Nepal 2011). 
The results also indicate the importance of community empowerment around GPNP that leads to significant increases of income. Therefore, people around GPNP need to be given many options related to their livelihoods. Limited employment in rural areas or low income in agriculture production is a serious threat to the conservation of GPNP. The limitation of employment is a logical consequence of the presence of national parks. This is often the most common view of local people in many national parks, as reported by Garner et al. (2012). Therefore, practical management that emphasizes the need for community participation to find a balance between biodiversity conservation and the socio-economic fulfillment of dependence on forest resources is very important (Rawat and Chandra 2015).

Meanwhile, the low level of public knowledge is caused by poor communications conducted by park officers. The results of the study showed that people recognition of the resort officers was still very poor, although park officers often patrolled the area. The low intensity of communication between the resort officers and local people (Figure 2) has led to low knowledge about management zones and the GPNP rules (Table 3 ). The current friendship and interaction between resort officers and local communities were low, and need to intensify. Local communities who really knew the resort officers were only $24.18 \%$. In fact, good relations with the resort officers has strong impact on a positive perception towards park conservation, as reported by Fiolla and Jacobson (1995). Therefore, as an effort to optimize the park protection management, an indispensable effort is increasing the frequency of socialization and communication conducted by the resort officers.

The lack of knowledge on part zonation further puts pressure on the GPNP. This was evidenced by the people's views which tend to contradict the purpose of park protection. For example, this study found a statement of the local people, as follows: "........ if the local people are not given the access to the land around the village within the park, it means the park is more important to animals than humans ............" (Interview, August 4, 2017)

This means that local communities feel that park authority or conservationists and governments are generally more concerned about wildlife than human welfare. The same feeling of local people also occurs in the protection of wildlife in the Kashmir valley-India, as reported by Mir et al. (2015).

Subsequently, the pressure caused by agricultural land expansion also continues to occur. The agricultural expansion, on the one hand, may be limited to fulfill the household needs in subsistence level, but on the other hand, it can also be a form of income increase that leads to the accumulation of capital. For example, at present, there are oil palms planted by household in Melinsum village. It will be the real pressure when the economic success of the households that have the oil palm is used as a reference for generating income by other households. The expansion of oil palm crops done independently by households within the park will be difficult to prevent if it has been done by many households, because the planting expansion can be done at any time and scale. The land conversion opportunities are possible because the palm is currently the most profitable crop (Budidarsono et al. 2012a, 2012b). In addition, the selling price is relatively stable and there is a tendency to increase compared to other plantation commodities whose prices are more volatile (Djunaedi 2003; Diantoro 2011). The conversion of national park land into oil palm plantations has already occurred in Tesso Nilo National Park, Riau Province-Indonesia in a larger scale, because the perpetrators are not only local people but also capital owners from outside the village (Diantoro 2011).

Overcoming such a pressure, the efforts to generate incomes of the people around the park is a solution that must be done immediately, especially for villages or hamlets which are very vulnerable in terms of economy. Economy empowerment can be done by the formation of an economic cluster on the development of certain commodities outside the park area not far from the villages. Agricultural commodities developed should be profitable to be traded to other areas, so it will bring the flow of money to the villages around GPNP. Besides, there is a need to develop non-land based economic programs. These can be community programs on environmental services, tourism, or putting more values on non-timber forest products. $\square$

\section{ACKNOWLEDGEMENTS}

We thanked IJ-REDD+ for commissioning this survey to Universitas Tanjungpura, Pontianak, Indonesia and authorizing the use of survey data in this publication. We are also in debt for sincere supports of all respondents in villages of Batu Barat (Matan Raya hamlet), Sedahan Jaya (Sawah, Tanjung Banjar, and Begasing hamlets), Pangkalan Buton (Air Pauh hamlet), Sejahtera (Tanjung Gunung and Melinsum hamlets) of Kayong Utara District, West Kalimantan, Indonesia.

\section{REFERENCES}

Arjunan M, Holmes C, Puyravaud JP, Davidar P. 2006. Do developmental initiatives influence local attitudes toward conservation? A case study from the Kalakad-Mundanthurai Tiger Reserve, India. J Environ Manag 79: 188-197.

Budidarsono S, Dewi S, Sofiyuddin M, Rahmanulloh A. 2012a. Socioeconomic impact assessment of palm oil production. Technical Brief No. 27: Palm Oil Series. World Agroforestry Centre (ICRAF), SEA Regional Office. Bogor, Indonesia.

Budidarsono S, Rahmanulloh A, Sofiyuddin M. 2012b. Economic assessment of palm oil production. Technical Brief No. 26: Palm Oil Series. World Agroforestry Centre (ICRAF), SEA Regional Office. Bogor, Indonesia.

Deni. 2011. Analisis perambahan hutan di Taman Nasional Bukit Barisan Selatan (Studi kasus Desa Tirom Kecamatan Pematang Sawa Kabupaten Tanggamus). Jurnal Ilmu Kehutanan 5 (1): 9-20. [Indonesian]

Diantoro TD. 2011. Perambahan kawasan hutan pada Konservasi Taman Nasional Tesso Nilo, Riau. Mimbar Hukum 23 (3): 546-565. [Indonesian]

Djunaedi I. 2003. Kebijakan pengembangan pengolahan kelapa sawit skala kecil (mini plant). Analisis Kebijakan Pertanian 1 (2): 1-9. [Indonesian]

Dove MR. 1988. Sistem perladangan di Indonesia. Gadjah Mada University Press. Yogyakarta. [Indonesian] 
Fiallo EA, Jacobson SK. 1995. Local communities and protected areas: Attitudes of rural residents toward conservation and Machalilla National Park, Ecuador. Environ Conserv 22 (3): 241-249.

Garner T, Najmanova K, Cihar M. 2012. Changes in local people's perceptions of the Sumava National Park in the Czech Republic over a ten year period (1998-2008). Sustainability 4: 1354-1370.

Hollenbach AJ. 2005. Promise or peril? The fate of indonesia's protected areas in an era of decentralization. J Dev Soc Transform 2: 79-87.

Htun NZ, Mizoue N, Yoshida S. 2012. Determinants of local people's perceptions and attitudes toward a protected area and its management: A case study from Popa Mountain Park, Central Myanmar. Soc Nat Resour 25: 743-758.

Infield M. 1988. Attitudes of a rural community towards conservation and a local conservation area in Natal, South Africa. Biol Conserv 45: 2146.

Kadir AW, Awang SA, Purwanto RS, Poedjirahajoe E. 2012. Analisis kondisi sosial ekonomi masyarakat sekitar Taman Nasional Bantimurung Bulusaraung, Provinsi Sulawesi Selatan. Jurnal Manusia dan Lingkungan 19 (1): 1-11. [Indonesian]

Kadir AW, Nurhaedah M, Purwanti R. 2013. Konflik pada kawasan Taman Nasional Bantimurung Bulusaraung Provinsi Sulawesi Selatan dan upaya penyelesaiannya. Jurnal Penelitian Sosial dan Ekonomi Kehutanan 10 (3): 86-198. [Indonesian]

Karanth KK, Nepal SK. 2011. Local residents perception of benefit and losses from protected areas in India and Nepal. Environ Manag 49 372-386.

Khalilzadeh J, Tasci ADA. 2017. Large sample size, significance level, and the effect size: Solutions to perils of using big data for academic research. Tourism Manag 62: 89-96.

Langton M, Rhea ZM, Palmer L. 2005. Community-oriented protected areas for indigenous peoples and local communities. J Pol Ecol 12: 23-50.

Mamo Y. 2015. Attitudes and perceptions of the local people towards benefits and conflicts they get from conservation of the Bale Mountains National Park and Mountain Nyala (Tragelaphus buxtoni), Ethiopia. Intl J Biodiv Conserv 7 (1): 28-40.

Megaze A, Balakrishnan M, Belay G. 2017. The attitudes and practices of local people towards wildlife in Chebera Churchura National Park, Ethiopia. Intl J Biodiv Conserv 9 (2): 45-55.
Mir ZR, Noor A, Habib B, Veeraswami GG. 2015. Attitude of local people toward wildlife conservation: A case study from the Kashmir Valley. Mountain Res Dev 35 (4): 392-400.

Nastran M, Istenic MC. 2015. Who is for or against the park? Factors influencing the public's perception of a regional park: A Slovenian case study. Human Ecol Rev 21 (2): 93-111.

Nastran M. 2015. Why does Nobody Ask Us ?. Impacts on local perception of a protected area in designation, Slovenia. Land Use Pol 46: 38-49.

Newmark WD, Leonard NL, Sariko HI, Gamassa DGM. 1993. Conservation attitudes of local people living adjacent to five protected area in Tanzania. Biol Conserv 63: 177-183.

Osunsina IOO, Fagbeyiro AO. 2015. Local community perception and attitude towards the non-utilization of natural resources in Old Oyo National Park, Oyo State, Nigeria. J Agric Environ Intl Dev 109 (2): 291-306.

Peeters MJ. 2016. Practical Significance: Moving beyond statistical significance. Curr Pharm Teach Learn 8 (1): 83-89.

Rawat VS, Chandra J. 2015. People of Nayar Valley and forest resource utilization. Intl J Innov Res Rev 3 (3): 1-5.

Schneider JW. 2013. Caveats for using statistical significance tests in research assessments. J Informetrics 7 (1): 50-62.

Shibia MG. 2010. Determinant of attitudes and perceptions on resource use and management of Marsabit National Reserve, Kenya. J Hum Ecol 30 (1): 55-62.

Silori CS. 2007. Perception of local people toward conservation of forest resources in Nanda Devi Biosphere Reserve, Nort-Western Himalaya, India. Biodiv Conserv 16: 211-222.

Tadesse SA, Taketay D. 2017. Perceptions and attitudes of local people toward participatory forest management in Tarmaber District of Nort Shewa Administrative Zone, Ethiopia: The case of Wof-Washa Forests. Ecol Process 6 (17). DOI: 10.1186/s13717-017-0084-6.

TNGP. 2009. Zonasi TNGP. Balai Taman Nasional Gunung Palung, Ketapang. [Indonesian]

Verbist B, Pasya G. 2004. Perspektif sejarah status kawasan hutan, konflik dan negosiasi di Sumberjaya, Lampung Barat, Propinsi Lampung. Agrivita 26 (1): 20-28. [Indonesian]

Yogaswara H. 2009. Taman nasional dalam wacana politik konservasi alam: Studi kasus pengelolaan Taman Nasional Gunung-Halimun Salak. Jurnal Kependudukan Indonesia 4 (1): 73-89. [Indonesian] 